\title{
DNA Damage Photoinduced by Cosmetic Pigments and Sunscreen Agents under Solar Exposure and Artificial UV Illumination
}

\author{
Hisao Hidaka $^{1 *}$, Hiroyuki Kobayashi ${ }^{1}$, Takayoshi KoIKE ${ }^{1}$, Tsugio SATo ${ }^{2}$ \\ and Nick SERPONE ${ }^{3 *}$ \\ ${ }^{1}$ Frontier Research Center for the Global Environment Science, Meisei University \\ (2-1-1 Hodokubo, Hino, Tokyo 191-8506, JAPAN) \\ ${ }^{2}$ Institute of Multidisciplinary Research for Advanced Materials, Tohoku University \\ (2-1-1 Katahira, Aoba-ku, Sendai, Miyagi 980-8577, JAPAN) \\ ${ }^{3}$ Dipartimento di Chimica Organica, Università di Pavia \\ (via Taramelli 10, Pavia 27100, ITALIA)
}

Edited by T. Itoh, Kitasato Univ., and accepted February 3, 2006 (received for review November 18, 2005)

\begin{abstract}
Nanostructured $\mathrm{ZnO}$ particles present in skin-care cosmetics and UVB/UVA sunscreen products generate strong oxidizing species (free radicals) when illuminated with UV radiation that can damages human skin and the horny layer. Damage to DNA by ZnO and other pigmentary ingredients in sunscreen formulations under artificial and solar UV exposure has been examined by Agarose gel electrophoresis using pUC 18 DNA plasmids (2686 base-pairs). Initial photoinduced oxidative damage done to DNA plasmids have been probed by nicking assays under in vitro conditions for $\mathrm{ZnO}$. The effects of nanosize $\mathrm{ZnO}$ and $\mathrm{CeO}_{2}$ particles, and the newly developed $\mathrm{CaO}$-doped and $\mathrm{SiO}_{2}$-coated $\mathrm{CeO}_{2}$ pigment are compared when subjected to artificial (75-W Hg-lamp) and solar UV radiation. Supercoiled DNA plasmids undergo one nick to produce the relaxed form, followed by a second nick yielding the linear form of the plasmids. The DNA constituents deoxyadenosine-5'-monophosphate (dAMP), guanosine-5'monophosphate (GMP) and cytidine-5'-monophosphate (CMP) have been examined to assess the photooxidative damage done to these nucleotides under photocatalytic conditions using the cosmetic/sunscreen $\mathrm{ZnO}$ pigment.

Adsorption of the nucleotide through the phosphate on the positively charged $\mathrm{ZnO}$ surface, followed by attack of the ribose/phosphate backbone by photogenerated $\cdot \mathrm{OH}$ (and/or $\cdot \mathrm{OOH})$ radicals on the $\mathrm{ZnO}$ surface lead to the degradation of the dAMP's ribose moiety and subsequently to decomposition of the adenine base residue. About $90 \%$ mineralization of the ribose/phosphate backbone occurred as evidenced by formation of $\mathrm{H}_{2} \mathrm{PO}_{4}^{-}$ions after only $30 \mathrm{~min}$ of UV irradiation. The nitrogen atoms of the adenine base were converted to $\mathrm{NO}_{3}{ }^{-}$and $\mathrm{NH}_{4}{ }^{+}$ ions. About $45 \%$ of the organic carbons constituting the dAMP ribose backbone was mineralized to $\mathrm{CO}_{2}$ within $8 \mathrm{~h}$ of $\mathrm{UV}$ irradiation occurring through formation of carboxylic acid intermediates (succinic, acetic and formic), with $85 \%$ of the remaining nucleobase ultimately mineralized after $48 \mathrm{~h}$ of UV irradiation. Similar occurrences were seen for the GMP and CMP
\end{abstract}

\footnotetext{
* Correspondence to: Hisao HidAKA, Department of Chemistry, Faculty of Science and Technology, Meisei University, 2-1-1, Hodokubo, Hino, Tokyo 191-8506, JAPAN

E-mail: hidaka@epfc.meisei-u.ac.jp

Nick SERPONE, Professor Emeritus, Concordia University, Montreal, CANADA

E-mail: nick.serpone@unipv.it
} 
nucleotides.

Key words: gel electrophoresis, DNA damage, sunscreen agent, cosmetic pigment, photooxidation, DNA plasmid

\section{Introduction}

Solar radiation induces acute and chronic reactions in human and animal skin, so much so that chronic repeated exposures to solar UVB/UVA radiation are the primary cause of benign and malignant skin tumours, including malignant melanoma (1). The solar UVA radiation $(320-400 \mathrm{~nm})$ reaching the surface of the Earth is about 20-fold greater than solar UVB (290-320 $\mathrm{nm}$ ) radiation (2). The longer wavelength UVA radiation penetrates the human skin to a greater (fivefold) depth than does UVB (3-5), reaching the region below the dermis that contains fibroblasts, dermal dendrocytes (dendritic cells with immune function), mast cells, macrophages, and lymphocytes (6). However, contrary to UVB radiation, UVA radiation is not readily absorbed by DNA. Rather, UVA is absorbed by endogenous photosensitizers generating reactive oxygen species such as superoxide radical anions $\left(\mathrm{O}_{2}^{--}\right)$, hydrogen peroxide $\left(\mathrm{H}_{2} \mathrm{O}_{2}\right)$, and/or $\bullet \mathrm{OH}$ radicals $(7,8)$ that can seriously damage DNA, membranes and other cellular components (2). Specific absorbers such as flavins, dehydrogenase co-enzymes of nicotineamide-adenine dinucleotide (NAD), flavin/adenine-dinucleotide (FAD), and flavin-mononucleotide (FMN) are present in living human cells. Accordingly, exposure to UVA light causes oxidative stress to these cells and radiationinduced immunosuppression (1, 8-10). For instance, oxidative stress causes such damage as formation of thymine glycol by peroxidation of thymine and hydrolysis of pyrimidine bases (11-14). As well, the adenine and guanine (purine) bases are also attacked by the reactive oxygen species, with cleavage of the imidazole ring in the guanine base.

The lower wavelength UVB radiation passes through the horny layer (stratum corneum) of the skin to reach the basement membrane below the stratum basale, and although it does not reach the dermis it nevertheless UV-illuminates the Langerhans cells, the keratinocytes and melanocytes present in the stratum spinosum and stratum basale (6). Compared to UVA, the solar UVB radiation is highly mutagenic and carcinogenic as evidenced in animal experiments. Epidemiological studies have also inferred that solar UV radiation is responsible for skin tumour development via gene mutations and immuno-suppression (1). Consequently, the UVB light that passes through the ozone layer in the stratosphere (15) and absorbed by the DNA in the various cells that constitute the epidermis causes the photo-production of DNA anomalous bases and derivatives in the configurational states of the DNA double helical chains. For instance, the cytosine and thymine bases in the DNA are either hydroxylated or deaminolyzed to generate unusual bases (16-19). In some cases, a pyrimidine dimer is formed (20).

White metal-oxide pigments such as $\mathrm{TiO}_{2}, \mathrm{Al}_{2} \mathrm{O}_{3}$, $\mathrm{ZnO}$ and others are commonly employed in cosmetic and sunscreen products. The pigments typically consist

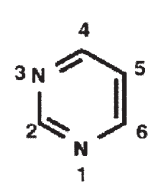

Pyrimidine

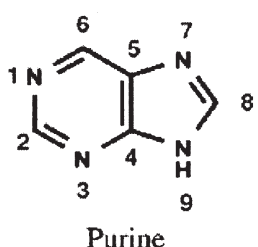

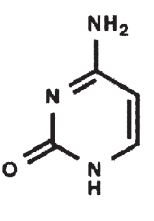

Cytosine<smiles>Cc1c[nH]c(=O)[nH]c1=O</smiles>

Thymine<smiles>O=c1cc[nH]c(=O)[nH]1</smiles>

Uracil<smiles>Nc1nc2[nH]cnc2c(=O)[nH]1</smiles>

Adenine 
of ultrafine particles with sizes smaller than $100 \mathrm{~nm}$ diameter. They screen ultraviolet light, are transparent and find acceptability as cosmetic and sunscreen materials. Sunscreen formulations are generally characterized by the sun protection factor (SPF) index in evaluating their performance at screening UV radiation (2123 ). (Note that the SPF stated for a sun protection product refers mostly to the UVB sun protection factor (24, 25)). The $\mathrm{TiO}_{2}$ rutile pigment presents better SPF characteristics than $\mathrm{ZnO}$. This notwithstanding, such metaloxide pigments play both a beneficial and a deleterious role. Although they screen UVA/UVB radiation efficiently, they can also generate harmful reactive oxygen species such as $\mathrm{O}_{2}^{-}, \mathrm{HOO}^{\circ}$ and ${ }^{\circ} \mathrm{OH}$, radicals (and even singlet oxygen, ${ }^{1} \mathrm{O}_{2}$, in the case of $\mathrm{TiO}_{2}$ (26)) when subjected to UVA/UVB radiation. These pigments are also well-known semiconductor photocatalysts having bandgap energies of $3.2 \mathrm{eV}$ (absorption edge, $387 \mathrm{~nm}$ ) for $\mathrm{TiO}_{2}$ anatase and $\mathrm{ZnO}$, and $3.0 \mathrm{eV}(414 \mathrm{~nm})$ for rutile $\mathrm{TiO}_{2}$. They have been investigated extensively in Advanced Oxidation Processes for environmental remediation. The bandgap energy of $\mathrm{CeO}_{2}$ particles is $3.1 \mathrm{eV}$ (absorption edge, $400 \mathrm{~nm}$ ). The $\mathrm{ZnO}$ pigment has lately been widely employed as the physical filter of choice in some sunscreen lotions over the micronized $\mathrm{TiO}_{2}$ (27).

DNA plasmids have been adopted as indicators of the photoactivity of metal-oxide specimens for examining in vivo damage to skin, injury to the stratum corneum and in some cases to DNA failure when exposed to solar UVB/UVA radiation. In this regard, in earlier studies we examined the photochemical damage done to DNA in the presence of $\mathrm{TiO}_{2}$ particles under exposure to UVA and UVB radiation (28-31). Possible effects that $\mathrm{CeO}_{2}$ (ceria) particulates might have on the initial photoinduced interaction with the DNA double helix and information on the photooxidation of DNA constituents such as deoxyadenosine-5'-monophosphate (dAMP), guanosine-5'-monophosphate (GMP), and cytidine-5'-monophosphate (CMP) were considered following recent articles by Yabe and Sato (32-36) on the synthesis and potential applications of various doped and coated $\mathrm{CeO}_{2}$ specimens proposed as potential cosmetic and sunscreen active agents. In the present report, we examine the DNA damage caused by the $\mathrm{ZnO}$ pigment in commercial sunscreen formulations (available in Japan) under in vitro conditions by UVB/UVA illumination. Changes to the forms of DNA plasmids from the Supercoiled (S), to the Relaxed (R), to the Linear (L) forms were investigated by Agarose gel electrophoresis for the newly developed $\mathrm{CaO}$-doped and $\mathrm{CaO}$-doped-SiO${ }_{2}$-coated $\mathrm{CeO}_{2}$ pigments. These changes are compared to those effected by naked $\mathrm{TiO}_{2}$, $\mathrm{ZnO}$ and $\mathrm{CeO}_{2}$ used as standards. In addition, the photooxidative damage induced by the $\mathrm{ZnO}$ pigment specimens extracted from the sunscreen lotions on the DNA plasmids and the constituent nucleotides dAMP, GMP, and CMP has been examined by monitoring the fate of the phosphate groups, the fate of the nitrogen atoms (formation of $\mathrm{NH}_{4}^{+}$and/or $\mathrm{NO}_{3}{ }^{-}$ions) and the fate of carbon atoms (evolution of $\mathrm{CO}_{2}$ ) of the ribose and the pyrimidine and purine nucleobase residues.

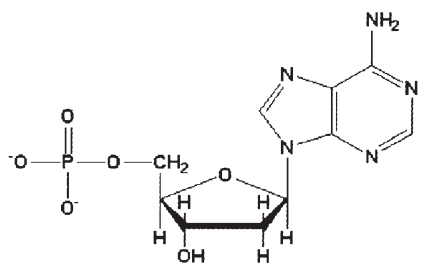

Deoxyadenosine monophosphate (dAMP)

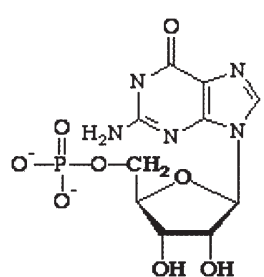

Guanosine monophosphate (GMP)

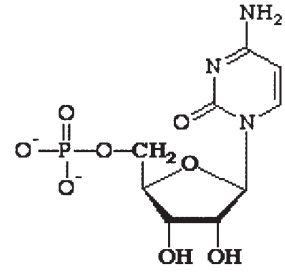

Cytidine monophosphate (CMP) 


\section{Experimental Section}

\subsection{Materials}

Nanostructured $\mathrm{TiO}_{2}$ (Degussa P-25) and $\mathrm{ZnO}$ (Wako) powdered specimens were used as reference samples. Since commercial sunscreens commonly include several additives (e.g. squalene, higher alcohols, fatty acid esters, glycerine, perfume and others), $5 \mathrm{~g}$ of the milky lotions containing the sunscreen active agents were treated with mixed acetone/methanol solvent (200 $\mathrm{mL}$ ) followed by sonication and filtration yielding a white powder that was subsequently used for further measurements. X-ray diffraction analysis of the crystalline structure of all the extracted sunscreen active agents confirmed the metal-oxide to be $\mathrm{ZnO}$. The following four newly $\mathrm{CeO}_{2}$ specimens developed by Yabe and Sato (32) were examined in powdered form: (a) naked $\mathrm{CeO}_{2}$, (b) $\mathrm{CaO}$-doped (20 mol \%) $\mathrm{CeO}_{2}$, (c) $\mathrm{CaO}$-doped $(20 \mathrm{~mol} \%) \mathrm{CeO}_{2}$ calcined at $700^{\circ} \mathrm{C}$, and (d) $\mathrm{CaO}$-doped (20 mol \%)-amorphous- $\mathrm{SiO}_{2}$-coated (10 wt \%) $\mathrm{CeO}_{2}$.

The $\mathrm{ZnO}$ pigments were extracted from four Japanese commercially available sunscreen lotions: (1) UV-Shield Sensitive J \{Oomi Kyoudaisha Mentam; SPF 32; PA ++\}, (2) Anessa Neosunscreen EX \{Shiseidou; SPF 50; PA +++\}, (3) Alli EX Cut Sunscreen R $\{$ Kanebo; SPF 50; PA +++$\}$, and (4) Super UV Screen N Waterproof $\{$ Kose; SPF 50; PA +++$\}$. The DNA plasmids were obtained from the $p U C 18 \mathrm{DNA}\left(\mathrm{A}_{260} / \mathrm{A}_{280}=\right.$ 1.76) that contained 2686 base-pairs; they were supplied by Nippon Gene Ltd. And were used as received without further treatment.

\section{$2 \cdot 2$ Analytical Procedures}

The concentration of phenol which was employed as a standard sample in the time profile of photocatalytic degradation activity in the filtrate was determined from its UV spectra using a JASCO V-570 spectrophotometer. The extent of mineralization of the substrates to $\mathrm{CO}_{2}$ was obtained with a Shimadzu GC-8A gas chromatograph equipped with a TCD detector and a Porapack Q column; helium was the carrier gas. Formation of $\mathrm{H}_{2} \mathrm{PO}_{4}^{-}, \mathrm{NH}_{4}^{+}$and $\mathrm{NO}_{3}^{-}$ions was assayed with a JASCO HPLC chromatograph, equipped with a CD-5 conductivity detector using either a Y-521 cationic column or an I-524 anionic column. Formation of carboxylic acid intermediates such as formic acid, acetic acid and succinic acid during the photooxidation of the various speciments was followed with a JASCO liquid chromatograph (HPLC) containing bromothymol blue (BTB); the column was a KC-811 and the UV detector was set at $445 \mathrm{~nm}$.

\subsection{Gel Electrophoresis Assessment for UV-illuminated DNA in vitro}

Gel electrophoretic experiments were carried out on a Funakoshi, model No. 1316R instrument (Tokyo, Japan) equipped with an ESP 250 power supply. A Kodak digital Science EDAS-290 analyzer system (Invistrogen Co. Ltd.) was used together with a Funakoshi (NTFM-20) 20-Watt UV-trans-illuminator.

The Agarose gel (1.75\%, Agarose S, Nippon Gene Ltd.) was added to $2 \mathrm{M}$ tris-acetate, 0.05-M EDTA buffered solution ( $\mathrm{pH} 8.0 ; 50 \mathrm{~mL})$ and subsequently dissolved using microwave- generated heat. The resulting Agarose solution was then poured into a UVT gel tray $(13 \mathrm{~cm} \times 16 \mathrm{~cm})$ to prepare a $3.5-\mathrm{mm}$ gel thin film. The above buffered solution was added to the gel electrophoresis tank (10mm deep), and before solidification of the thin layer gel a twenty-holes comb was appropriately located in the tray to prepare the thin film (30 $\mathrm{min}$ ). The white $\mathrm{ZnO}$ specimens (10 $\mathrm{mg}$ ) extracted from the sunscreen lotions were placed in a $10-\mathrm{mL}$ cylindrical vessel containing deionized water $(9 \mathrm{~mL})$. Subsequently, a $1-\mu \mathrm{L}$ specimen of $p U C 18$ DNA was added to $20 \mu \mathrm{L}$ of the $\mathrm{ZnO}$ dispersion in Petri dish. Irradiation of the dispersions was carried out with a $75 \mathrm{~W} \mathrm{Hg}$ lamp (Toshiba SHL-100UVQ-2) emitting an irradiance of $c a$. $3.4 \pm 0.3 \mathrm{~mW} \mathrm{~cm}^{-2}$ in the wavelength range 310 to 400 $\mathrm{nm}$ (maximal emission at $\lambda=360 \mathrm{~nm}$ ). Each experiment at all wavelengths without interference filter were done. After illumination, a $1-\mu \mathrm{L}$ sample was collected in a microtube and stored in a refrigerator for later use. Subsequently, a $1-\mu \mathrm{L}$ solution of an ethidium bromide dye solution was added to the stored illuminated samples, followed by addition of $8 \mu \mathrm{L}$ of deionized water and further agitation to insure good mixing. The samples were then injected into each well of the Agarose gel tank. Electrophoresis was performed under an applied voltage of $100 \mathrm{~V}$ for $2 \mathrm{~h}$. The gel samples were irradiated with the UV trans-illuminator, and the emission from the dye-strained DNA was recorded with a digital camera. The relative quantity of the three configurations $(\mathrm{S}, \mathrm{R}$, and $\mathrm{L})$ of the DNA plasmids present in the gel samples was determined using a EDSA-290 densitometer. 


\section{Results and Discussion}

Sunscreen active agents are so-called either physical or chemical filters. The former typically comprise white $\mathrm{ZnO}$ and micronized $\mathrm{TiO}_{2}$, whereas the latter (organic) filter comprises such substances as Padimate-O, Parsol 1789, octylmethoxycinnamate, and others (37). Metal oxides such as $\mathrm{CeO}_{2}$ and $\mathrm{ZrO}_{2}$ particulates with sizes smaller than ca. $100 \mathrm{~nm}$ are also being examined for incorporated in cosmetics and sunscreen commercial products (38-49). However, naked ceria particles are pale yellow and highly oxidizing, but less than $\mathrm{TiO}_{2}$ and $\mathrm{ZnO}$ (48), making them nonetheless unsuitable for use in cosmetics and as sunscreen active agents (46). Accordingly, the $\mathrm{CeO}_{2}$ particles have in some cases been modified by coating with boron nitride (BN), which effectively reduce both thermal and photocatalytic activity toward the oxidation of castor oil. The BNcoated $\mathrm{CeO}_{2}$ specimens displayed higher transparency and greater effectiveness at UV shielding than either $\mathrm{TiO}_{2}$ or $\mathrm{ZnO}$ particles $(41,44,46)$. A variety of metalion doped ceria particulate systems have also been reported. They displayed small particle size $(2-4 \mathrm{~nm})$, increased absorption characteristics in the UV region and greater transparency in the visible region relative to an equivalent quantity of micronized $\mathrm{TiO}_{2}(32-34,40$, 45). Calcium oxide doping of $\mathrm{CeO}_{2}(20 \mathrm{~mol} \%)$ imparts greater photostability relative to naked ceria particles, and coating with a layer of amorphous $\mathrm{SiO}_{2}$ enhances particle integrity (48). It was therefore appropriate to examine the behaviour of these particulate specimens toward DNA.

The double helical DNA structure undergoes damage under UV illumination with the white pigments (e.g., $\mathrm{TiO}_{2}$ ) used as active physical agents in cosmetic and in sunscreen formulations (37). The initial DNA plasmids typically consist of the supercoiled form (S), which upon UV exposure to UV radiation showed a pattern of two bands in the nicking assay (Fig. 1(a)): a lower band corresponds to the supercoiled (S) plasmids and the upper band belongs to the relaxed (R) form of the plasmids. To assess the behaviour of the various $\mathrm{CeO}_{2}$ specimens toward DNA, two other white pigments $\mathrm{TiO}_{2}(\mathrm{P}-$ 25) and $\mathrm{ZnO}$ (Wako) were also examined as reference and were subjected to otherwise identical conditions as the ceria specimens.

In the presence of $\mathrm{TiO}_{2}$, the supercoiled DNA configuration decreased significantly within ca. $30 \mathrm{~min}$ of exposure to UV illumination, the band becoming barely visible after $30 \mathrm{~min}$ (Fig. 1(b)). Concomitantly, the band intensity of the relaxed form increased rapidly after only 15 min of irradiation. Further UV illumination of the $\mathrm{TiO}_{2}$-DNA specimen caused another band to appear after ca. 30 min sandwiched between the $\mathrm{S}$ and $\mathrm{R}$ bands: this band corresponds to the linear (L) form of the DNA plasmids $(28,50)$. In the presence of the $\mathrm{ZnO}$ pigment, the $\mathrm{S}$ band intensity decreased relatively early after only 15 min of UV irradiation (Fig. 1(c)); at the same time the $\mathrm{L}$ band appeared intensified. Thereon, the $\mathrm{R}$ band decreased in intensity, whereas the $\mathrm{L}$ band became more pronounced. Beyond $30 \mathrm{~min}$ of irradiation, the supercoiled structure of the DNA plasmids was no longer observable. Compared to the behaviour of the $\mathrm{TiO}_{2}$-DNA sample, it is evident that the $\mathrm{ZnO}$ pigment imparted a faster and greater damage to the DNA plasmids.

The gel electrophoresis patterns with respect to naked $\mathrm{CeO}_{2}$-DNA system are illustrated in Fig. 1(d). Contrary to the $\mathrm{TiO}_{2}$ and $\mathrm{ZnO}$ pigments, the number of

(a)

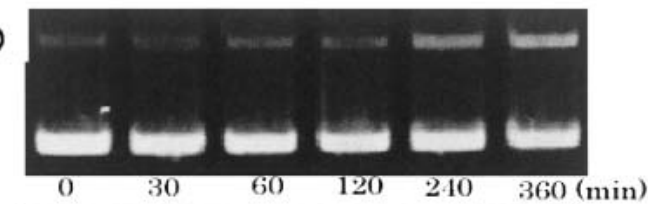

(b)

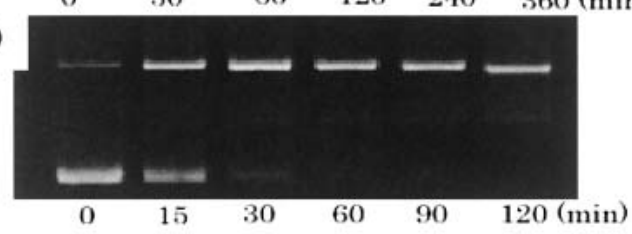

(c)

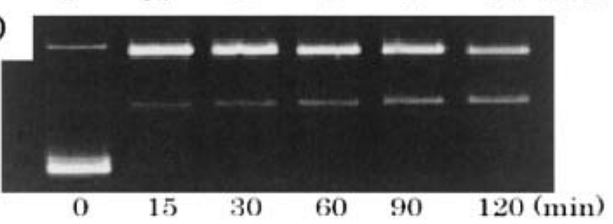

(d)

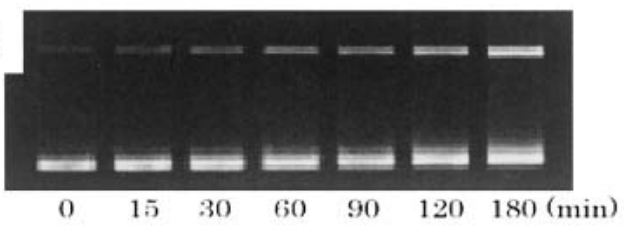

Fig. 1 Pictures of Gel Electrophoresis Samples Showing DNA Damage as a Result of UV Irradiation $(\mathrm{Hg}$ Lamp; Light Irradiance, $3.4 \pm 0.3 \mathrm{~mW} \mathrm{~cm}^{-2}$ at 360 $\mathrm{nm}$ ): (a) pigment-free DNA, (b) DNA plasmids in the presence of $\mathrm{TiO}_{2}$ particles (Degussa P-25), (c) DNA plasmids in the presence of $\mathrm{ZnO}$, and (d) DNA in the presence of naked $\mathrm{CeO}_{2}$ particles. 
surpercoiled DNA plasmids ( $\mathrm{S}$ band) in the $\mathrm{CeO}_{2}$-DNA system gradually decreased with increasing illumination time, whereas the number of relaxed plasmids increased. No L band was evident even after $180 \mathrm{~min}$ of UV irradiation. Clearly, the naked $\mathrm{CeO}_{2}$ particles caused far less damage to the DNA plasmids upon UV illumination than either of the more phohtoactive $\mathrm{TiO}_{2}$ and $\mathrm{ZnO}$ reference pigments.

The temporal changes in the relative intensity of supercoiled, relaxed and linear bands in the gel electrophoresis patterns for damage to the DNA plasmids caused by the $\mathrm{ZnO}$ pigment, which was extracted from

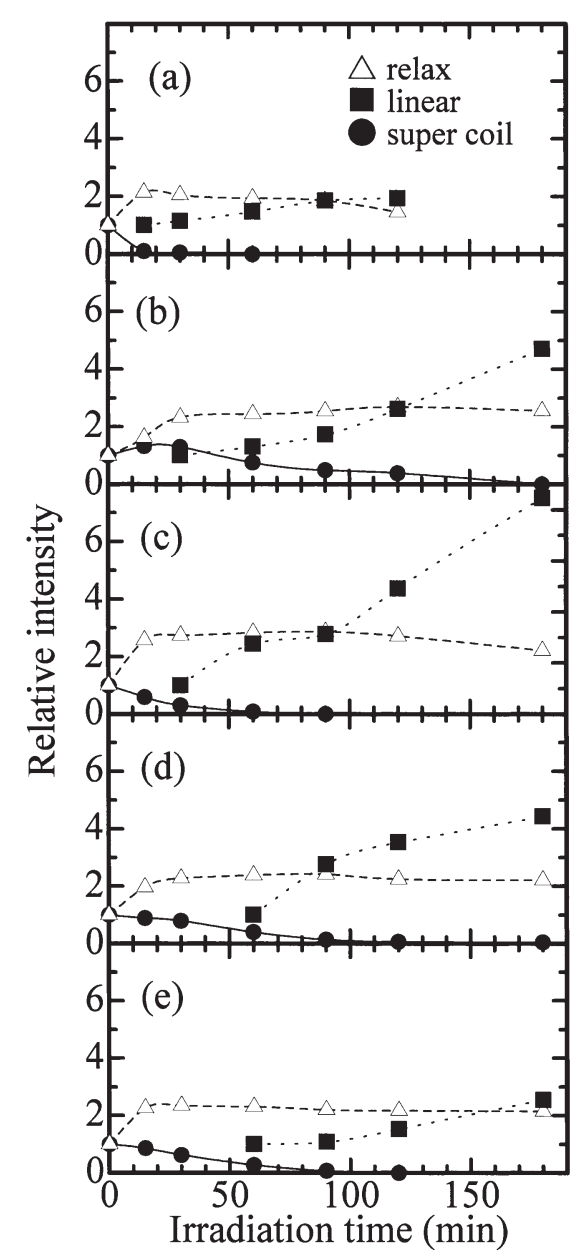

Fig. 2 Relative Intensity of the Bands Corresponding to the Supercoiled $(\mathbf{O})$, Relaxed $(\Delta)$ and Linear $(\mathbf{\square})$ Forms of the DNA Plasmids as a Function of Irradiation Time of the white $\mathrm{ZnO}$ Pigments: (a) pristine $\mathrm{ZnO}$ (Wako); and $\mathrm{ZnO}$ from commercial sunscreen lotions (b) Anessa Neosunscreen EX, (c) UV-Shield Sensitive J, (d) Alli EX Cut Sunscreen R, and (e) Super UV Screen N Waterproof. the commercial sunscreen lotions, are shown in Fig. 2(a)-2(e). The corresponding results for a pristine sample of $\mathrm{ZnO}$ (Wako) are displayed in Fig. 2(a).

All the $\mathrm{ZnO}$ specimens extracted from sunscreen lotions caused considerable damage to the DNA plasmids which increased in the order: $\{$ Wako $\mathrm{ZnO}\} \approx\{$ Super UV Screen N Waterproof (SPF 50, PA +++$)\}<\{$ Alli EX Cut Sunscreen R (SPF 50, PA +++) $\} \approx\{$ Anessa Neosunscreen EX (SPF 50, PA +++$)\}<\{$ UV-Shield Sensitive J $(\mathrm{SPF} 32, \mathrm{PA}++)\}$. Clearly, the most photoactive sunscreen active $\mathrm{ZnO}$ pigment for DNA damage amongst the commercial sunscreens was from the UV-Shield Sensitivite J lotion, whereas the least photoactive $\mathrm{ZnO}$ specimen was from the Super UV Screen N Waterproof sunscreen lotion. These observations accord with the SPF index and the PA index used for commercial inorganic/nanosized UV shielding metal-oxide pigments. Interestingly, the pristine $\mathrm{ZnO}$ specimen (Wako) displayed lower photoactivity toward nicking DNA plasmids than the commercial pigments.

The $\mathrm{CeO}_{2}$ specimen has most of the prerequisite properties in applications as a skin-protective sunscreen agent since it is transparent to visible light, it has excellent characteristics for adsorption of UV light, the particle size is below $100 \mathrm{~nm}$, and displays natural skin transparency $(38,39,42,47,48)$. These fine characteristics notwithstanding, however, $\mathrm{CeO}_{2}$ particles also display unusually high oxidation catalytic activity toward oxidation of many organic substances $(31,43-45)$. Consequently, $\mathrm{CeO}_{2}$ particles have seldom been used until now. Accordingly, $\mathrm{CeO}_{2}$ particulates were modified by doping with various metal ions, in particular with $\mathrm{Ca}^{2+}$ ( $\mathrm{CaO}$ after calcinations), and coated with an amorphous layer of $\mathrm{SiO}_{2}$. The photoactivity of these modified ceria specimens were examined to assess the oxidative activity toward DNA plasmids and oxidation of phenol (compared with the photooxidative ability of $\mathrm{P}-25 \mathrm{TiO}_{2}$ - see below), and their suitability as possible sunscreen and cosmetic pigments.

The effects of surface-modified $\mathrm{CeO}_{2}$ powder specimens toward injury to DNA plasmids subjected to artificial UV radiation ( $\mathrm{Hg}$ light source) are reported in Fig. 3(a)- 3(d), where in the temporal damage done to the supercoiled (S) DNA plasmids and the evolution of the relaxed $(\mathrm{R})$ and linear $(\mathrm{L})$ configurations of DNA for (a) naked $\mathrm{CeO}_{2}$ alone, (b) $\mathrm{CaO}$-doped (20 mol \%) $\mathrm{CeO}_{2}$, (c) $\mathrm{CaO}$-doped (20 mol \%) $\mathrm{CeO}_{2}$ calcined at 700 ${ }^{\circ} \mathrm{C}$ and (d) $\mathrm{CaO}$-doped (20 mol \%)-amorphous- $\mathrm{SiO}_{2}$ - 
coated ( $10 \mathrm{wt} \%) \mathrm{CeO}_{2}$ is compared. The coating with a $\mathrm{SiO}_{2}$ layer should prevent conversion of the supercoiled configuration to relaxed and/or linear forms. Results of exposing the same $\mathrm{CeO}_{2}$ speciemens/DNA plasmid systems to solar UV radiation are illustrated in Fig. 3(e)3(h).

Cerium oxide particles alone show little photoactivity toward damage to the DNA plasmids as evidenced by the relative stability of the supercoiled form and the slow evolution of the relaxed DNA plasmids under both artificial and solar UV exposure (Fig. 3(a) and 3(e)). By comparison, although barely visible, the $\mathrm{CaO}$-doped $\mathrm{CeO}_{2}$ specimen caused some of the supercoiled plasmids to evolve also into the linear form at the longer irradiation times (beyond $60 \mathrm{~min}$; Fig. 3(b) and 3(f)) through consecutive nicks of the DNA structure. The calcined $\mathrm{CaO}$-doped $\mathrm{CeO}_{2}$ specimen shows some linear plasmids (the L band) as well, subsequent to solar UV exposure (Fig. 3(g)), but not to artificial UV radiation
(Fig. 3(c)). By contrast, no linear plasmids are evidently formed when the DNA plasmids are subjected to artificial and solar UV radiation in the presence of the $\mathrm{CaO}$-doped-amorphous- $\mathrm{SiO}_{2}$-coated ceria specimen (Fig. 3(d) and 3(h)).

Both $\mathrm{TiO}_{2}$ and $\mathrm{ZnO}$ fine particles used in cosmetic and sunscreen products exhibit relatively high photoactivity toward degradation of cosmetic constituents, damage to DNA (28), and promotion of skin senescence (photoaging) by photogenerated reactive oxygen species $(51,52)$, such as $\cdot \mathrm{OH}$ and $\cdot \mathrm{OOH}$ radicals, superoxide radical anions $\left(\mathrm{O}_{2}^{-\cdot}\right)$ and singlet oxygen $\left({ }^{1} \mathrm{O}_{2}\right)$, and $\mathrm{H}_{2} \mathrm{O}_{2}$. Incomplete photoprotection against the solar UVA radiation also causes skin senescence (53). Another troubling issue with these cosmetic pigments is the whitening phenomenon on human skin. Coating of $\mathrm{CeO}_{2}$ particles with amorphous silica diminishes UV intrusion into the skin as they are stronger UV absorbers and thus better UV blockers. Moreover, their

(a)
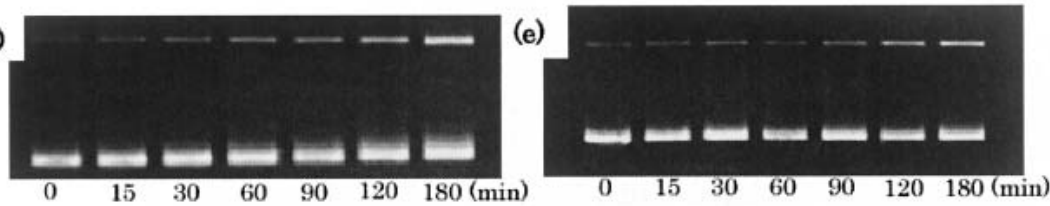

(b)

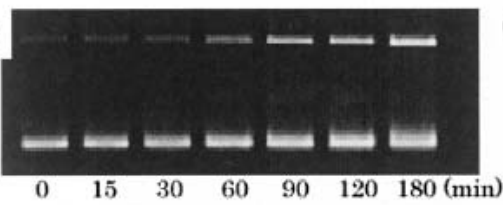

(f)

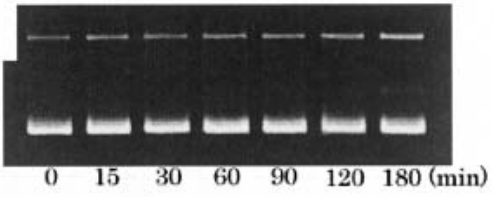

(c)
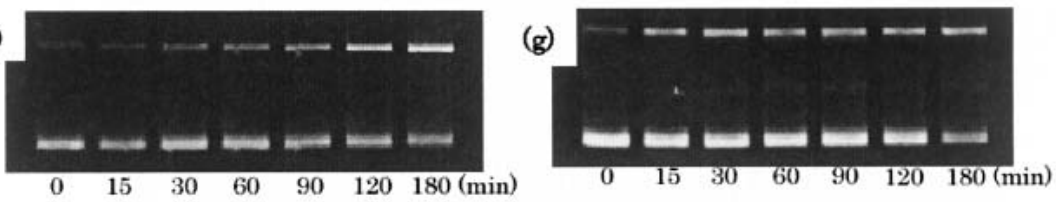

(d)

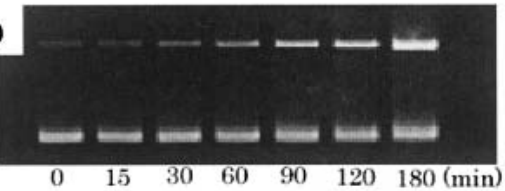

(h)

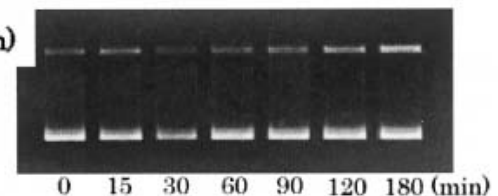

Fig. 3 Left Hand Panels Display the Nicking Results from Gel Electrophoresis Measurements Showing the Photoinduced Damage Caused to DNA Plasmids under UV-illumination with a Hg Lamp Emitting a Light Irradiance of $3.8 \pm 0.4 \mathrm{~mW} \mathrm{~cm}{ }^{-2}$ at $360 \mathrm{~nm}$ for (a) naked $\mathrm{CeO}_{2}$ alone, (b) $\mathrm{CaO}$-doped $(20 \mathrm{~mol} \%) \mathrm{CeO}_{2}$, (c) $\mathrm{CaO}$-doped (20 mol\%) $\mathrm{CeO}_{2}$ calcined at $700{ }^{\circ} \mathrm{C}$ and (d) $\mathrm{CaO}$-doped $(20 \mathrm{~mol} \%)$-amorphous-SiO${ }_{2}$-coated $(10 \mathrm{wt}$ \%) $\mathrm{CeO}_{2}$. The right hand panels illustrate the nicks photoinduced on the DNA plasmids under solar exposure (light irradiance, $3.7 \pm 0.2 \mathrm{~mW} \mathrm{~cm}^{-2}$ at $360 \mathrm{~nm}$ ) for (e) naked $\mathrm{CeO}_{2}$ alone, (f) $\mathrm{CaO}$-doped $\left(20 \mathrm{~mol}^{\circ}\right) \mathrm{CeO}_{2}$, (g) $\mathrm{CaO}$-doped $(20 \mathrm{~mol} \%) \mathrm{CeO}_{2}$ calcined at $700{ }^{\circ} \mathrm{C}$, and (h) $\mathrm{CaO}$-doped $\left(20 \mathrm{~mol} \%\right.$ )-amorphous- $\mathrm{SiO}_{2}$-coated (10 wt \%) $\mathrm{CeO}_{2}$. In all the panels, the lowest band corresponds to the $\mathrm{S}$ form of DNA, the upper band is that of the $\mathrm{R}$ form, and the middle band (where visible) corresponds to the $\mathrm{L}$ form of the DNA plasmids. 
photoactivity is also diminished. Doping $\mathrm{CeO}_{2}$ particles with metal ions also depresses the photoactivity of ceria $(32,44-46)$.

The temporal relative stability of the supercoiled DNA plasmid structure and the evolution of the relaxed structure under artifical UV light are illustrated in Fig. 4. Formation of relaxed plasmids increased during the 3 $\mathrm{h}$ of UV irradiation, indicating that some of the supercoiled plasmids were nicked to evolve into the relaxed form. Since the hydrogen bonds composing the double helical supercoiled configuration are $c a$. 25-fold weaker

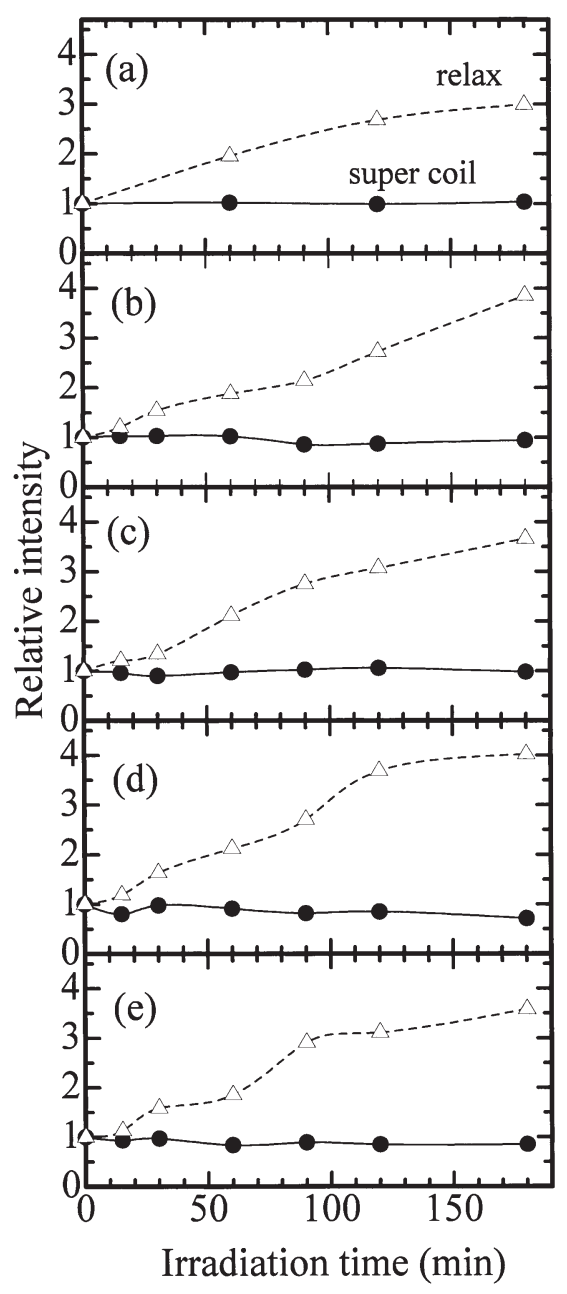

Fig. 4 Temporal Relative Intensity of Supercoiled (O) and Relaxed $(\Delta)$ Configurations Subsequent to UV Irradiation of DNA Plasmids with the 75-Watt Hg Light Source in the Presence of (a) pigment-free system, (b) naked $\mathrm{CeO}_{2}$ alone, (c) $\mathrm{CaO}$-doped (20 mol \%) $\mathrm{CeO}_{2}$, (d) $\mathrm{CaO}$ (20 mol \%)-doped $\mathrm{CeO}_{2}$ calcined at $700^{\circ} \mathrm{C}$, and (e) $\mathrm{CaO}(20 \mathrm{~mol} \%)$-dopedamorphous- $\mathrm{SiO}_{2}$-coated (10 wt \%) $\mathrm{CeO}_{2}$. than the common covalent bond, the supercoiled helix easily unwinds to the relaxed configuration when nicked by reactive oxygen species produced under irradiation. By comparison relative to the DNA plasmids are subjected to the UV radiation (Fig. 4(a)), the presence of the other four modified ceria specimens showed a slightly greater number of relaxed plasmids after $3 \mathrm{~h}$ of irradiation (Fig. 4(b) to 4(e)).

The photooxidative activity of various sunscreen ingredients on the degradation of phenol $(0.1 \mathrm{mM})$ was examined. Results are reported in Fig. 5. Phenol decomposed in less than 40 min with $\mathrm{TiO}_{2}$ particles (P25) through first order kinetics. Compared to this very active titania specimen, the four ceria speciments were relatively photoinactive in degrading phenol (naked $\mathrm{CeO}_{2}$ alone was ca. 50 times less active than $\mathrm{TiO}_{2}$ ). Amongst the four $\mathrm{CeO}_{2}$ systems, the $\mathrm{CaO}$-doped-amorphous- $\mathrm{SiO}_{2}$-coated $\mathrm{CeO}_{2}$ specimen was the least photoactive in degrading phenol for the $1 \mathrm{~h}$ of UV irradiation. The quentity of phenol that degraded in the presence of naked $\mathrm{CeO}_{2}$ amounted to about a $10 \%$ drop in the initial concetration after $60 \mathrm{~min}$ of UV irradiation.

We next examined the fate of the DNA linear plasmids further under UV irradiation (Hg light source; 75 Watts). These linear plasmids were produced from $p U C$ 18 DNA using the Hind III restriction enzyme and then were examined by gel electrophoresis in the absence of

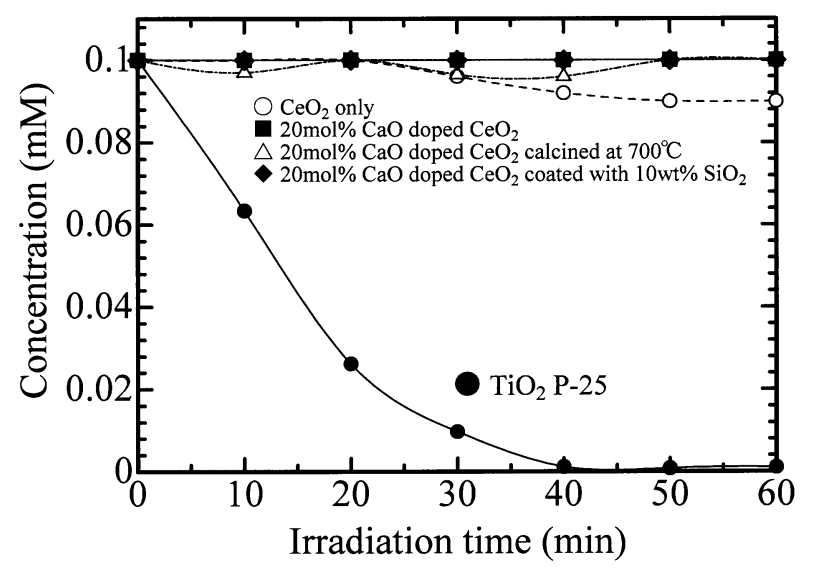

Fig. 5 Temporal Course of the Degradation of Phenol (0.1 $\mathrm{mM})$ under UV Irradiation in the Presence of $\mathrm{TiO}_{2}$ (P-25) particulates $(\mathrm{O})$ and $\mathrm{CeO}_{2}$ Specimens: naked $\mathrm{CeO}_{2}(\bigcirc)$; CaO-doped (20 mol \%) $\mathrm{CeO}_{2}(\square)$; $\mathrm{CaO}$ doped $(20 \mathrm{~mol} \%) \mathrm{CeO}_{2}$ calcined at $700^{\circ} \mathrm{C}(\Delta)$; and CaO-doped (20 mol \%)-amorphous- $\mathrm{SiO}_{2}$-coated (10 wt \%) $\mathrm{CeO}_{2}(\nabla)$. 
$\mathrm{ZnO}$ (Fig. 6(a)) and presnece of the $\mathrm{ZnO}$ pigment (Fig. 6(b)). The linear DNA plasmids were very stable to UV irradiation for up to $6 \mathrm{~h}$ when no pigmentary $\mathrm{ZnO}$ was present. However, in the presence of $\mathrm{ZnO}$ followed by UV irradiation the linear plasmids were totally degraded after $3 \mathrm{~h}$ (the $\mathrm{L}$ band was no longer visible after this time - Fig. 6(b)). \{Note that the first assay in Fig. 6(b) is that of the supercoiled DNA plasmids and is shown for comparison only\}. Clearly, the above evidence suggests that the double helical configuration of the linear plasmid was not damaged by UV radiation alone. However, in the presence of the $\mathrm{ZnO}$ pigment known to produce $\cdot \mathrm{OH}$ radicals (and other reactive oxygen species see above) when subjected to UV irradiation, these radicals induced considerable damage to the plasmids through oxidation of a number of the 2686 base pairs.

To examine what the fate of some of the constituents of the DNA plasmids may be in the presence of such a photoactive sunscreen pigment as $\mathrm{ZnO}$ when subjected to UV irradiation for long periods, we next examined the photooxidative degradation of three dAMP, GMP and CMP nucleotides, under photocatalytic conditions otherwise typically used in Advanced Oxidation Processes. The temporal course of the photodegradation of the dAMP nucleotide monitored through the evolution of mineralized products is illustrated in Fig. 7.

Exposure of dAMP to UV irradiation in the presence
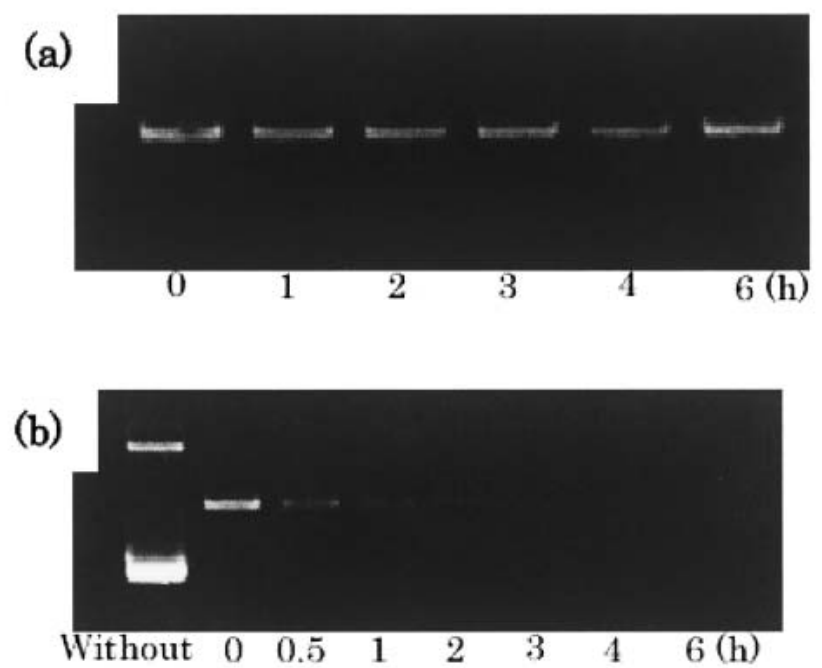

Fig. 6 Pictures of Gel Electrophoresis Patterns on the Photodamage Caused to the Linear Structure of the DNA Plasmids Prepared from $p U C 18$ DNA using the Hind III Restriction Enzyme for (a) a ZnO-free system and (b) in the Presence of the $\mathrm{ZnO}$ Pigment. of $\mathrm{ZnO}$ for $36 \mathrm{~h}(1.5 \mathrm{~d})$ led to the photomineralization of this nucleotide, as evidenced by formation of dihydrogenphosphate anions, ammonium ions and nitrate ions. During the initial stage, the $\mathrm{H}_{2} \mathrm{PO}_{4}^{-}$ion is rapidly formed in less than $0.5 \mathrm{~h}(c a .0 .045 \mathrm{mM})$ and then just rapidly (in less than $1 \mathrm{~h}$ ) about half of the initial quantity of $\mathrm{H}_{2} \mathrm{PO}_{4}{ }^{-}$adsorbed on the positively charged $\mathrm{ZnO}$ particle surface. Continued irradiation gradually increases the quantity of the $\mathrm{H}_{2} \mathrm{PO}_{4}^{-}$ions to $\mathrm{ca}$. 0.026 $\mathrm{mM}$ after 36 h. Concomitantly, $\mathrm{NH}_{4}{ }^{+}$cations and $\mathrm{NO}_{3}{ }^{-}$ anions also formed rapidly initially and then more slowly tending to $c a$. $0.040 \mathrm{mM}$ for nitrate ions and $c a$. $0.055 \mathrm{mM}$ for ammonium ions. On continued irradiation, the latter were further oxidized to $\mathrm{NO}_{3}^{-}$reaching $0.1 \mathrm{mM}$ after $36 \mathrm{~h}$ through prior formation of a hydrox-

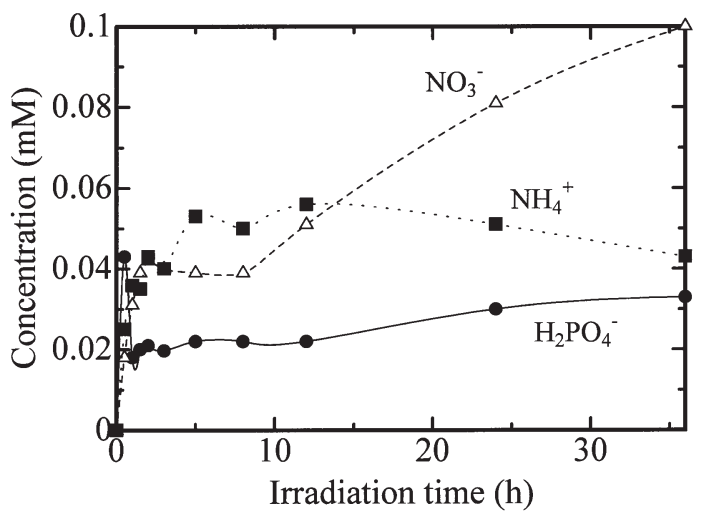

Fig. 7 Photocatalytic Mineralization of the dAMP Nucleotide in the Presence of $\mathrm{ZnO}$ Yielding $\mathrm{H}_{2} \mathrm{PO}_{4}^{-}$Ions from the Breakup of the RibosePhosphate Backbone of the Nucleotide, and $\mathrm{NH}_{4}^{+}$and $\mathrm{NO}_{3}^{-}$Ions from the Degradation of the Adenine Base Residue.

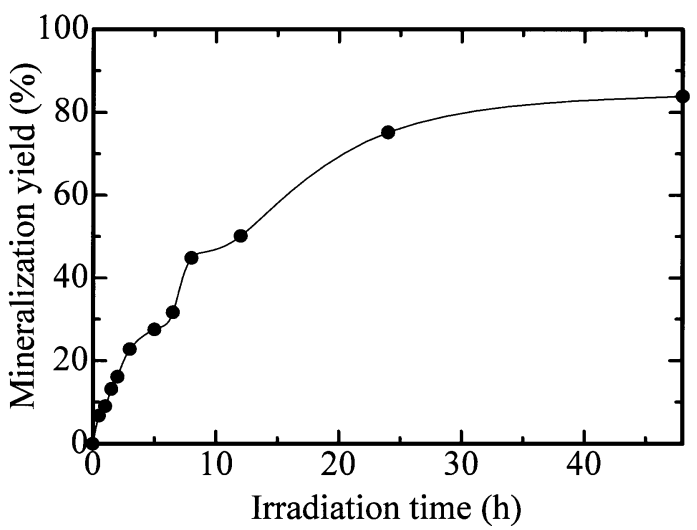

Fig. 8 Evolution of $\mathrm{CO}_{2} \mathrm{Gas}$ in the Photodegradation of dAMP with $\mathrm{ZnO}$ Pigment. 


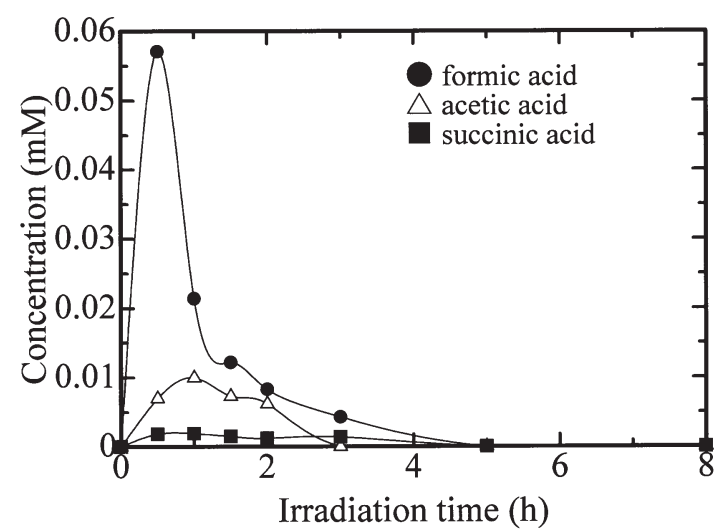

Fig. 9 Formation of Formic, Acetic and Succinic Acids in the Photodegradation of dAMP in Aqueous ZnO Dispersions.

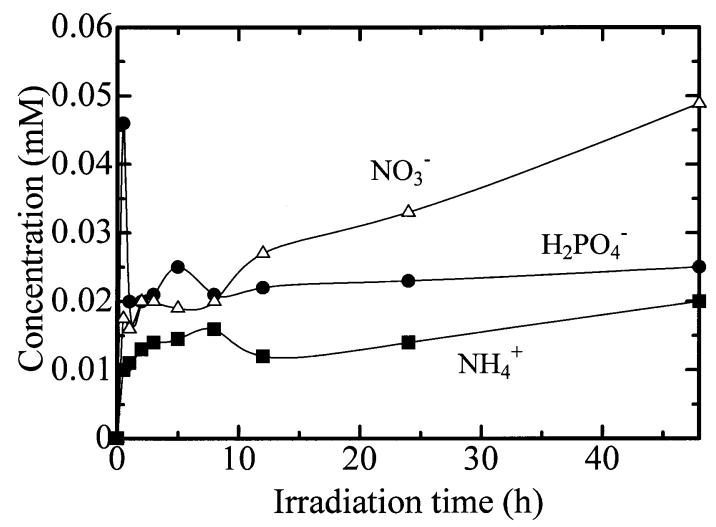

Fig. 10 Formation of $\mathrm{H}_{2} \mathrm{PO}_{4}^{-}, \mathrm{NH}_{4}{ }^{+}$and $\mathrm{NO}_{3}^{-}$Ions in the Photodegradation of GMP with $\mathrm{ZnO}$ Pigment.

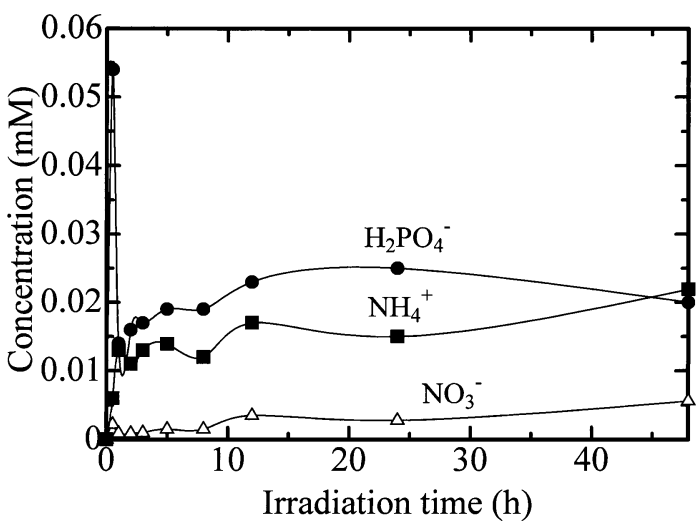

Fig. 11 Formation of $\mathrm{H}_{2} \mathrm{PO}_{4}^{-}, \mathrm{NH}_{4}{ }^{+}$and $\mathrm{NO}_{3}{ }^{-}$Ions in the Photodegradation of CMP with $\mathrm{ZnO}$ Pigment. ylamine $(-\mathrm{HNOH})$ moiety and $\mathrm{NO}_{2}^{-}$ions. The degradation of adenosine was also confirmed by monitoring the evolution of carbon dioxide by gas chromatography (Fig. 8). The level of mineralization of this nucleoside (includes the ribose moiety) to $\mathrm{CO}_{2}$ gas reached $\sim 83 \%$ after $2 \mathrm{~d}$ of UV irradiation through prior formation of carboxylic acid intermediate species (succinic, acetic and formic acids; Fig. 9).

The GMP and CMP nucleotides were also photomineralized under other conditions otherwise identical to those used for the degradation of the deoxyadenosine nucleotide. The corresponding temporal evolution of $\mathrm{H}_{2} \mathrm{PO}_{4}{ }^{-}$ions, $\mathrm{NH}_{4}{ }^{+}$and $\mathrm{NO}_{3}{ }^{-}$ions are illustrated in Fig. 10 and 11, respectively. In both cases, the dihydrogenphosphate anions formed fairly rapidly, followed by rapid adsorption onto the $\mathrm{ZnO}$ surface as evidenced by the rapid drop in concentration within a few minutes. For the guanosinemonophosphate nucleotide, a greater quantity of nitrate ions formed relative to ammonium ions. By contrast, for the CMP nucleotide, the quantity of $\mathrm{NO}_{3}{ }^{-}$ion produced was significantly lower than that of $\mathrm{NH}_{4}{ }^{+}$ions. Such differences are likely due to structural differences between the guanine base (a purine) and the cytosine base (a pyrimidine). Note the similarities in the degradation of the adenine and guanine, both purine bases, and their contrast with the pyrimidine base cytosine.

\section{Concluding Remarks}

The zinc oxide pigment used in cosmetics and as a sunscreen active agent in commercial formulations causes significant damage to DNA under UV illumination. In line with earlier observations $(28,36)$, nicks on the supercoiuled DNA plasmids were caused by $\cdot \mathrm{OH}$ radicals photogenerated on UV-irradiated $\mathrm{ZnO}$. The DNA constituent nucleotides dAMP, GMP and CMP undergo fairly rapid degradation in the presence of the $\mathrm{ZnO}$ pigment exposed to UV radiation producing dihydrogenphosphate, ammonium and nitrate ions. Evidently, the $\cdot \mathrm{OH}$ radicals attack both the ribose and the deoxyadenosine, guanosine, and cytidine nucleotides within $c a .30 \mathrm{~min}$ of irradiation. The $\mathrm{CeO}_{2}$ speciments were less photoactive than the corresponding metal oxides $\mathrm{TiO}_{2}$ and $\mathrm{ZnO}$ toward phenol and DNA plasmids. Consequently, the $\mathrm{CeO}_{2}$ specimens would be preferred as physical filters in cosmetics and sunscreen lotions over the other two metal oxides. The $\mathrm{CaO}$ - 


\section{DNA Damage Photoinduced by Cosmetic Pigments}

doped-amorphous- $\mathrm{SiO}_{2}$-coated $\mathrm{CeO}_{2}$ system tended to be the least photoactive of the four ceria speria specimens examined.

\section{Acknowledgments}

The work carried out in Tokyo was suppoted by the "Academic Frontier" Project for Private Universities with a matching fund subsidy from the Japanese Ministry of Education, Culture, Sports, Science and Technology (MEXT) for the period of 2003 2007, as well as from a Grant-in-Aid for Science Research (No. 17550145; MEXT: to H.H.). Studies carried out in Pavia were supported by a grant (to N.S.) from the Ministero dell' Universita e della Ricerca (MIUR-Rome, Italy). Finally, we also wish to thank Prof. J. Knowland of Oxford University for several useful discussions on the matter of chemical sunscreen active agents.

\section{References}

1. M. ICHIHASHI, M. UEDA, A. BUDIYANTO, T. BITO, M. OKA, M. FUKUNAGA, K. TSURU and T. HORIKAWA, UVinduced Skin Damage, Toxicol., Vol. 189, 21-39 (2003).

2. F.R. de GUIJL, Photocarcinogenesis: UVA vs UVB, Methods Enzymol., Vol. 319, 359-366 (2000).

3. Y.-Y. HE, J.-L. HUANG, R.H. SIK, J. LIU, M.P. WAALKES and C.F. CHIGNELL, Expression Profiling of Human Keratinocyte Response to Ultraviolet A: Implications to Apoptosis, J. Investig. Dermatol., Vol. 122, 533-543 (2004).

4. K. HOFFMANN, K. KASPAR, P. ALTMEYER and T. GAMBICHLER, UV Transmission Measurements of Small Skin Specimens with Special Quartz Cuvettes, Dermatol., Vol. 201, 307311 (2000).

5. G. EGGSET, G. KAVLI, H. KROKAN and G. VOLNER, Ultraviolet and Visible Light Penetration of Epidermis, Photobiochem. Photobiophys., Vol. 8, 163-167 (1984).

6. J.T. HU and B. WANG, Microanatomy and Histology of Skin, MMI, McGill University, Montreal, Canada (2000), http://sprojects.mmi.mcgill.ca/dermatology/dermis.htm.

7. M. BUDAI, A. REYNAUD-ANGELIN, Z. SZABO, S. TOTH, G. RONTO, E. SAGA and P. GROF, Effect of UVA Radiation on Membrane Fluidity and Radical Decay in Human Fibroblasts as Detected by Spin Labelled Stearic Acids, J. Photochem. Photobiol. B:Biol., Vol. 77, 27-38 (2004).

8. W.-H. CHAN, C.-C. WU and J.-S. YU, Curcumin Inhibits UV Irradiation-Induced Oxidative Stress and Apoptotic Biochemical Changes in Human Epidermoid Carcinoma A431 Cells, J. Cell. Biochem., Vol. 90, 327-338 (2003).

9. J.M. KUCHEL, R.St.C. BARNETSON and G.M. HALLIDAY, Nitric Oxide Appears to be a Mediator of Solar-Simulated Ultra- violet Radiation-Induced Immunosuppression in Humans, $J$. Investig. Dermatol., Vol. 121, 587-593 (2003).

10. J. YODOI, H. NAKAMURA, H. MASUTANI, Y. NISHINAKA and I. HATTORI, The Role of Thio-Redoxin in Regulatory Cellular Functions, in Cellular Implications of Redox Signalling (C. GITLER and A. DANON, eds.), Imperial College Press, London, pp. 115-140 (2003).

11. L.N. DANIEL, Y. MAO, T.-C.L. WANG, C.J. MARKEY, S.P. MARKEY, X. SHIM and U. SAFFIOTTI, DNA Strand Breakage, Thymine Glycol Production, and Hydroxyl Radical Generation Induced by Different Samples of Crystalline Silica in vitro, Environ. Res., Vol. 71, 60-73 (1995).

12. K. YAMANAKA, M. MIZOI, M. TACHIKAWA, A. HASEGAWA, M. HOSHINO and S. OKADA, Oxidative DNA Damage Following Exposure to Dimethylarsinous: the Formation of cis-thymine Glycol, Toxicol. Letters, Vol. 143, 145-153 (2003).

13. O.I. ARUOMA, B. HALLIWELL, E. GAJEWSKI and M. DIZDAROGLU, Copper-Ion-Dependent Damage to the Bases of DNA in the Presence of Hydrogen Peroxide, Biochem. J., Vol. 273, 601-604 (1991).

14. B. DEMPLE and S. LINN, 5,6-Saturated Thymine Lesions in DNA: Production by Ultraviolet Light or Hydrogen Peroxide, Nuclei Acids Res., Vol. 10, 3781-3789 (1982).

15. A.J. BLAKE and J.H. CARVER, The Evolutionary Role of Atmospheric Ozone, J. Atmospheric Sci., Vol. 34, 720-728 (1977).

16. M. DIZDAROGLU, A. KARAKAYA, P. JARUGA, G. SLUPPAUG and H.E. KROKAN, Novel Activities of Human Uracil DNA N-glycosylase for Cytosine-Derived Products of Oxidative DNA Damage, Nucleic Acids Res., Vol. 24, 418-422 (1996).

17. G. CRISTALLI, A. ELEUTERI, S. VITTORI, R. VOLPINI, E. CAMAIONI and G. LUPIDI, Adenosine Deaminase Inhibitors: Structure-Activity Relationships in 1-deazaadenosine and Erythro-9-(2-hydroxy-3-nonyl)adenine Analogs, Drug Develop. Res., Vol. 28, 253-258 (1993).

18. R.C. HARTENSTEIN and I. FRIDOVICH, Adenine Aminohydrolase. An Investigation of Specificity, J. Biol. Chem., Vol. 242, 740-746 (1967).

19. S.C. AGARWALA, C.R.K. MURTI, D.L. SHRIVASTAVA and A.S. GUPTA, Metabolism of Purine and Pyrimidine Compounds by Vibrios, Enzymologia, Vol. 16, 322-328 (1954).

20. C.A. CHADWICK, C.S. POTTEN, O. NIKAIDO, T. MATSUNAGA, C. PROBY and A.R. YOUNG, The Detection of Cyclobutane Thymine Dimers, (6-4) Photolesions and the Dewar Photo-Isomers in Sections of UV-irradiated Human Skin Using Specific Antibodies, and the Demonstration of Depth Penetration Effects, J. Photochem. Photobiol. B:Biol., Vol. 28, 163-170 (1995).

21. United States Federal Register: May 21, 1999, Vol. 64, No. 98; DOCID: fr21my99-6; Sunscreen Drug Products for Over-TheCounter Human Use - Final Monograph, http://vm.cfsan.fda.gov/ $\sim \operatorname{lrd} /$ fr990521.html.

22. R. HOFMANN-WELLENHOF, J. SMOLLE, A. ROSCHGEN, 
D. STRUNK, M. HUBMER, C. HOFFMANN, F. QUEHANBERGER, M. HORN, H. KERL and P. WOLF, Sunburn Cell Formation, Dendritic Cell Migration, and Immunomodulatory Factor Production after Solar-Simulated Irradiation of SunscreenTreated Human Skin Explants in vitro, J. Investig. Dermatol., Vol. 123, 781-787 (2004).

23. T. TAKEUCHI, J. UITTO and E.F. BURNSTEIN, A Novel in vivo Model for Evaluating Agents that Protect Against Ultraviolet A-induced Photoaging, J. Investig. Dermatol., Vol. 110, 343 347 (1998)

24. F. BERNERD, C. VIOUX, F. LEJEUNE and D. ASSELINEAU, The Sun Protection Factor (SPF) Inadequately Defines Broad Spectrum Protection: Demonstration Using Skin Reconstructed in vitro Exposed to UVA, UVB or UV-solar Simulated Radiation, Eur. J. Dermatol., Vol. 13, 242-249 (2003).

25. H. STEGE, M. BUDDE, S. GRETHER-BECK, A. RICHARD, A. ROUGIER, T. RUZICKA and J. KRUTMANN, Sunscreens with High SPF Values are not Equivalent in Protection from UVA Induced Polymorphous Light Eruption, Eur. J. Dermatol., Vol. 12, iv-vi (2002).

26. Y. NOSAKA, T. DAIMON, A.Y. NOSAKA and Y. MURAKAMI, Singlet Oxygen Formation in Photocatalytic $\mathrm{TiO}_{2}$ Aqueous Suspension, Phys. Chem. Chem. Phys., Vol. 6, $2917-2918$ (2004).

27. T. TSUZUKI, M. NEARN and G.J. TROTTER (Advanced Powder Technology Pty. Ltd. Australia), Substantially Visibly Transparent Topical Physical Sunscreen Formulation, U.S. Patent Appl. Publ. (2003); Application U.S. 2002-324112 20021220; PCT Int. Appl. (2003), Patent Application WO 2003-AU239 20030227.

28. R. DUNFORD, A. SALINARO, L. CAI, N. SERPONE, S. HORIKOSHI, H. HIDAKA and J. KNOWLAND, Chemical Oxidation and DNA Damage Catalyzed by Inorganic Sunscreen Ingredients, FEBS Lett., Vol. 418, 87-90 (1997).

29. H. HIDAKA, S. HORIKOSHI, N. SERPONE and J. KNOWLAND, In vitro Photochemical Damage to DNA, RNA, and Their Bases by an Inorganic Sunscreen Agent under UV-A and UV-B Radiation, J. Photochem. Photobiol. A: Chem., Vol. 111, 205-213 (1997).

30. S. HORIKOSHI, N. SERPONE, S. YOSHIZAWA, J. KNOWLAND and H. HIDAKA, Photocatalyzed Degradation of Polymers in Aqueous Semiconductor Suspensions. IV. Theoretical and Experimental Examination of the Photooxidative Mineralization of Constituent Bases in Nucleic Acids at Titania/Water Interfaces, J. Photochem. Photobiol. A: Chem., Vol. 120, 63-74 (1999).

31. H. HIDAKA, H. KOBAYASHI, M. KUGA and T. KOIKE, Photoinduced Characteristics of Metal-oxide Cosmetic Pigments by Agarose Gel Electrophoresis of DNA Plasmids in vitro under UV-illumination, J. Oleo Sci., Vol. 54, 487-494 (2005).

32. S. YABE and T. SATO, Cerium Oxide for Sunscreen Cosmetics, J. Solid State Chem., Vol. 171, 7-11 (2003).

33. S. YABE, M. YAMASHITA, S. MOMOSE, S. YOSHIDA, K. HASEGAWA, S. YIN and T. SATO, Synthesis and Photochemical Properties of Calcia-Doped Ceria Nanoparticles Coated with
Amorphous Silica, J. Soc. Inorg. Mater. Jpn., Vol. 8, 428-433 (2001).

34. S. YABE, M. YAMASHITA, S. MOMOSE, K. TAHIRA, S. YOSHIDA, R. LI, S. YIN and T. SATO, Synthesis and UVshielding Properties of Metal Oxide Doped Ceria via Soft Solution Chemical Processes, Int. J. Inorg. Mater., Vol. 3, 1003-1008 (2001).

35. M. YAMASHITA, K. KAMEYAMA, S. YABE, S. YOSHIDA, Y. FUJISHIRO, T. KAWAI and T. SATO, Synthesis and Microstructure of Calcia Doped Ceria as UV Filters, J. Mater. Sci., Vol. 37, 683-687 (2002).

36. R. LI, S. YABE, M. YAMASHITA, S. MOMOSE, S. YOSHIDA, S. YIN and T. SATO, UV- shielding Properties of Zinc OxideDoped Ceria Fine Powders Derived via Soft Solution Chemical Routes, Mater. Chem. Phys., Vol. 75, 39-44 (2002).

37. N. SERPONE, A. SALINARO, A.V. EMELINE, S. HORIKOSHI, H. HIDAKA and J. ZHAO, An in vitro Systematic Spectroscopic Examination of the Photostabilities of a Random Set of Commercial Sunscreen Lotions and Their chemical UVB/UVA Active Agents, Photochem. Photobiol. Sci., Vol. 1, 970-981 (2002).

38. L. ZHANG, Inorganic Nanometer Sunscreening Skin-Nursing Cosmetic, Faming Zhuanli Shenqing Gongkai Shuomingshou, Patent Application: CN 2002-111489 20020425 (2002).

39. H. OKA, K. YAMAJI and T. KANZAKI, Inorganic Oxide Dispersions Having Excellent Transparency and UV-shielding Propertu and Their Preparation, Jpn. Kokai Tokkyo Koho, Patent Application: JP 2002-191725 2002070 (2004).

40. N. YABE and S. KAZUHIRO, Sunscreen Compositions Containing Metal Oxide-Doped Ceria Solid Solution Particles, Jpn. Kokai Tokkyo Koho, Patent Application: JP 2001-98125 20010330 (2002).

41. T. MASUI, M. YAMAMOTO and G.-y. ADACHI, Synthesis of Ceria-Based UV Blocking Material, Kidorui, 34, pp. 60-61 (1999).

42. T. SAEKI, Apatite Complex Particles Containing Ceria for Cosmetics, Jpn. Kokai Tokkyo Koho, Patent Application: JP $93-$ 13537319930512 (1994).

43. K. OKADA and K. TANAKA, Sunscreens Containing SilicaCeria Composite Particles, Jpn. Kokai Tokkyo Koho, Patent Application: JP 99-109886 19990313 (2000).

44. M. YAMAMOTO, T. MASUI and G.-y. ADACHI, Development of a BN-coated Ceria-Based UV Blocking Material, Kidorui, Vol. 36, 86-87 (2000).

45. S. YABE and S. MOMOSE, Cerium Dioxide - Silica Complex: a Novel, Non-Reactive and Transparent UV Absorber for Cosmetics, Proc. $3^{\text {rd }}$. Scientific Conference of the Asian Societies of Cosmetic Chemists, Asian Societies of Cosmetic Chemists Publ., Taipei, Taiwan, pp. 103-110 (1997).

46. T. MASUI, M. YAMAMOTO, R. HAMADA and G.-y. ADACHI, Synthesis of BN-coated Cerium (IV) Oxide Fine Particles and Their Application as UV Blocking Materials, Shikizai Kyokaishi, Vol. 73, 429-433 (2000).

47. T. ASAGOE, I. ISOHATA, T. MATSUMURA and O. HONMA, 


\section{DNA Damage Photoinduced by Cosmetic Pigments}

Sunscreens Containing Cerium Oxide, Jpn. Kokai Tokkyo Koho, Patent Application: JP 88- 23255419880919 (1990).

48. S. YABE and T. SATO, Development of Cerium Oxide as a Novel UV filter, Shikizai Kyokaishi, Vol. 73, 615-623 (2000).

49. K. WAKABAYASHI, M. KISHIDA and T. TAKO, Inorganic Oxides as UV Ray-Shielding Agents, Jpn. Kokai Tokkyo Koho, Patent Application: JP 2002-51558 20020227 (2003),

50. N. SERPONE, A. SALINARO, S. HORIKOSHI and H. HIDAKA, Beneficial Effects of Photo-inactive Titanium Dioxide Specimens on Plasmid DNA, Human Cells and Yeast Cells Exposed to UVA/UVB Simulated-Sunlight, J. Photochem. Photobiol. A: Chem., Vol. 179, 200-212 (2006).

51. M. WLASCHEK, I. TANTCHEVA-POOR, L. NADERI, W. MA, L.-A. SCHNEIDER, Z. RAZI-WOLF, J. SCHULLER and K.
SCHARFFTTER-KOCHANEK, Solar UV Irradiation and Dermal Photoageing, J. Photochem. Photobiol. B: Biol., Vol. 63, 4151 (2001).

52. M. WLASCHEK, I. TANTCHEVA-POOR, P. BRENNEISEN, L. KUHR, Z. RAZI-WOLF, C. HELLWEG, L.-A. SCHNEIDER, C. MEEWES and K. SCHARFFTTER-KOCHANEK, The Negative Effects of Solar and Artificial Irradiation: Photoaging of the Skin, Its Clinical Appearance and Underlying Mechanisms, Comprehensive Ser. Photosci., Vol. 115, 117-130 (2001).

53. L. MARROT, J.P. BELAIDI, F. LEJEUNE, J.R. MEUNIER, D. ASSELINEAU and F. BERNERD, Photostabulity of Sunscreen Products Influences the Efficiency of Protection with Regard to UV-induced Genotoxic or Photoageing-Related Endpoints, Brit. J. Dermatol., Vol. 151, 1234-1244 (2004). 